\title{
Ta szkoła symbolicznie rozstrzelała się sama... Filmy Stoń, Carrie, Nad krawędzia w dyskusji o problemach współczesnej szkoły i młodzieży podczas zajęć z pedagogiki na specjalnościach nauczycielskich
}

KEY WORDS

feature film, methodology of teacher training, contemporary problems of young people

\begin{abstract}
Jaskulska Sylwia, "Ta szkoła symbolicznie rozstrzelała się sama...". Filmy "Słoń", "Carrie", "Nad krawędzią" w dyskusji o problemach współczesnej szkoły i młodzieży podczas zajęć z pedagogiki na specjalnościach nauczycielskich [This School Has Symbolically Shot Itself... The Elephant, Carrie and Over the Edge Films in the Debate on the Problems Faced by Contemporary Schools and Young People During Pedagogy Classes for Trainee Teachers]. Kultura - Społeczeństwo - Edukacja nr 2(10) 2016, Poznań 2016, pp. 315-327, Adam Mickiewicz University Press. ISSN 2300-0422. DOI 10.14746/kse. 2016.10.24.

In the paper, apart from interpreting the message of films: Carrie (directed by Brian De Palma), Over the Edge (directed by Jonathan Kaplan) and Elephant (directed by Gus Van Sant), I also describe how classes can be arranged around them. Thus, I join the debate on the space for such productions in education, especially in the methodology for training teachers-to-be. I indicate possible applications of feature films and a wide spectrum of benefits that follow from this approach. In fact, movies are still an undervalued but very effective didactic tool that engages pupils in authentic intellectual tasks that deal with important content and issues.
\end{abstract}

Od kilku lat prowadzę zajęcia $\mathrm{z}$ pedagogiki na specjalnościach nauczycielskich (na Wydziale Filologii Polskiej, Angielskiej, Wydziale Matematyki i Informatyki Uniwersytetu im. Adama Mickiewicza w Poznaniu). Studenci przygotowujący się do pracy w zawodzie nauczyciela niezmiennie dziwią się, gdy na liście obo- 
wiązkowej literatury widzą książkę Carrie autorstwa Stevena Kinga (często z adnotacją: lub obejrzenie filmu Briana De Palmy z 1976 r.). Na liście obowiązkowych tekstów kultury znajduje się także film Nad krawędziq w reżyserii Jonathana Kaplana, a podczas zajęć (zwykle wieńczących cały kurs), na których omawiamy te dzieła, wspólnie oglądamy film Słoń (reż. Gus Van Sant). Gdyby pokusić się o sformułowanie jak najbardziej ogólnego tematu tych zajęć, brzmiałby on: problemy współczesnej szkoły i młodzieży. W dalszej części tekstu przybliżę treść filmów i szerzej przedstawię problematykę poruszaną podczas zajęć.

Opisując własne doświadczenia dydaktyczne, spróbuję zatem wskazać możliwości wykorzystania filmów fabularnych podczas zajęć z pedagogiki na specjalnościach nauczycielskich. Włączę się tym samym w dyskusję nad miejscem tego typu filmów w edukacji, szczególnie w metodyce kształcenia przyszłych nauczycieli.

Książka Carrie Stevena Kinga, na podstawie której powstał film, opowiada historię dorastającej dziewczyny. Jej matka, fanatyczka religijna, wychowuje córkę, stosując przemoc fizyczną i psychiczną (np. zamykanie na wiele godzin w ciemnym pomieszczeniu za każdy popełniony „grzech”). Autor wiele miejsca poświęcił rzekomym zdolnościom telekinetycznym dziewczyny - potrafi ona na przykład przenosić siłą woli przedmioty. Carrie odstaje od rówieśników - matka narzuca jej konserwatywny ubiór i zachowanie. Nastolatka jest odrzucona i wyśmiewana. W wyniku szkolnego spisku dziewczyna idzie na bal zaproszona przez jednego z najbardziej popularnych chłopców w szkole, zostaje nawet królową balu. Gdy na chwilę odzyskuje wiarę w siebie, do akcji wkraczają koledzy i koleżanki dziewczyny i wybrzmiewają ostatnie akordy spisku. Oblewają tytułową bohaterkę wiadrem świńskiej krwi na widoku całej szkolnej społeczności. Carrie, z pomocą telekinezy, dewastuje szkołę, zabija wielu rówieśników i nauczycieli, a potem demoluje całe miasto.

Film Nad krawędziq pokazuje życie nastolatków z przedmieścia. Ich codzienność jest nudna i monotonna. Cały wolny czas spędzają w centrum rekreacji - to teren pod miastem z placem zabaw i hangarem, w którym znajdują się stoły do ping-ponga, kanapy itp. W dzień młodzi ludzie bawią się tam, grają i dyskutują, nocami piją alkohol i odurzają się narkotykami. Z powodu nudy dokonują drobnych przestępstw - akcja zaczyna się od zabawy, w trakcie której jeden $\mathrm{z}$ chłopców strzela $\mathrm{z}$ pistoletu $\mathrm{w}$ radiowóz. Rozwścieczony policjant, kierowca radiowozu, zaczyna akcję przeciwko „rozwydrzeniu” młodzież z New Grenady. W tym samym czasie w miasteczku toczą się negocjacje - teren rekreacji na być sprzedany inwestorowi, milionerowi z Meksyku. Młodzież protestuje, nasilają się zamieszki. Dochodzi do wypadku - podczas pościgu policjant śmiertelnie postrzelił jednego $\mathrm{z}$ chłopców. Punktem kulminacyjnym fabuły jest spo- 
tkanie w szkole - zaproszeni są na nie tylko dorośli: rodzice i nauczyciele. Mają debatować o zdarzeniu i o przestępczości nieletnich, okazuje się jednak, że organizatorzy spotkania bardziej martwią się o pomyślne ubicie targu z inwestorem niż o uczniów szkoły. Chcą im odebrać centrum rekreacji, które przedstawiane jest jako gniazdo wszelkiego zła. Rozwścieczeni uczniowie blokują wszystkie wyjścia i zamykają dorosłych w szkole. Demolują ich samochody, wzniecają pożar, dewastują okolicę szkoły. Ginie jeden z policjantów. W ostatniej scenie widzimy szkolny autobus wypełniony młodzieżą. Pod eskortą policji wyjeżdża z miasta (prawdopodobnie dzieciaki trafią do jakiegoś ośrodka wychowawczego).

W warstwie fabularnej film Słoń opowiada o dwóch chłopcach, którzy planują dzień zagłady w swojej szkole. Kupują broń, przyjeżdżają do szkoły i strzelają. Giną uczniowie, nauczyciele, dyrekcja. Film Van Santa jest trudny w odbiorze nie tylko ze względu na tematykę. Od początku do sceny strzelaniny (ostatnie minuty filmu) prawie nic się nie dzieje. Uczniowie leniwie przemieszczają się po szkole, rozmawiają. Czasem przez kilka minut dyskretna, wręcz intymna kamera podąża za uczniem, który samotnie przemierza szkolne korytarze czy boisko. Nieprzypadkowo reżyser zadbał o to, żeby widz znał bohaterów z imienia. Gdy każdy z nich pojawia się pierwszy raz, na ekranie widzimy imię. Leniwe snucie się po szkole za bohaterami pokazuje, że ich życie jest zwyczajne, to niczym nie wyróżniający się dzień dla tej szkolnej społeczności. Widzimy dosłownie kilka minut szkolnego dnia, ciągle to samo, tylko z punktu widzenia różnych osób. Przed wspólnym oglądaniem filmu dzielę studentów na grupy. Każda z nich ma oglądać film z perspektywy jednego z bohaterów ${ }^{1}$. Są to na przykład: John, który w drodze do szkoły zauważa, że ojciec znów jest pijany. Musi sam usiąść za kierownicą, zorganizować ojcu opiekę, przez co spóźnia się do szkoły i dostaje naganę, bo dyrektor nie chce słuchać usprawiedliwień. Michelle - dziewczyna wyśmiewana przez rówieśniczki w szatni. Jest tak pełna kompleksów, że nie potrafi się przebrać przy koleżankach, co niedelikatnie komentuje jej nauczycielka. Brittany, Jordan i Nicole plotkują podczas posiłku w szkolnej stołówce o chłopakach, ciuchach i znajomych, po czym nie przestając rozmawiać udają się do łazienki i wymiotują.

${ }^{1}$ Inspiracją do takiego sposobu wykorzystania filmu Słoń były warsztaty, które podczas XVIII Letniej Szkoły Młodych Pedagogów (W poszukiwaniu nowoczesnej szkoły, Łagów Lubuski, 30.08-04.09.2004) przeprowadzili właśnie wokół tego obrazu dr Lidia Wawryk i dr Artur Doliński oraz treść wykładu wprowadzającego w problematykę tejże LSM prof. Marii Dudzikowej (Nauczyciel-uczeń z perspektywy symbolicznego interakcjonizmu. Na przykładzie analizy „Belfra” J.D. Dopagne’a oraz „Nauczycieli” Stawomira Mrożka). Niektóre wątki tego wykładu zostały opublikowane w książce autorstwa prof. M. Dudzikowej pt. Pomyśl siebie... Minieseje dla wychowawcy klasy (2007). Przywołuję je w dalszej części tekstu. Z czasem wypracowałam w oparciu o te treści własny scenariusz zajęć $\mathrm{z}$ wykorzystaniem także filmów Carrie i Nad krawędziq. 
Są też Alex i Eric, którzy zamawiają przez Internet broń i strzelają do uczniów. O tych bohaterach dowiadujemy się trochę więcej niż o pozostałych. Widzimy scenę, w której koledzy obrzucają Alexa podczas lekcji kulkami z papieru. Nauczyciel albo udaje, albo rzeczywiście nie widzi, że taka sytuacja ma miejsce. Nie reaguje. Jedyny moment filmu, kiedy akcja przenosi się poza mury szkoły i jej najbliższe otoczenie to scena, w której zaglądamy do domu jednego z chłopców. Drugi nocuje u niego. Widzimy codzienne życie nastolatków korzystających z gier komputerowych, jeden z nich ćwiczy grę na pianinie, jedzą przygotowane przez mamę śniadania, żegnają śpieszących się do pracy rodziców. Jednak czujemy, że ta sielanka to tylko cisza przed burzą (twórcy filmu pokazują to dosłownie, widzimy płynące po niebie chmury). W filmie Słoń wielokrotnie powraca pewien niepokój wynikający z paradoksów, których doświadczamy. $\mathrm{Z}$ pozoru wszystko jest leniwe, bezpieczne. Jak zauważa $\mathrm{w}$ recenzji filmu napisanej po rozdaniu nagród w Cannes Richard Porton, reżyser obnaża w filmie konformizm i biurokratyczne zaślepienie przeciętnej amerykańskiej szkoły średniej (Porton, 2003: 52). Nauczyciele śmieją się, prowadzą z uczniami dyskusje na ważne tematy, w szkole obowiązują standardy bezpieczeństwa (np. monitorowanie wyjść ze szkoły podczas lekcji). W tej idealnej szkole dyrektor karze jednak ucznia, który spóźnia się do szkoły nie z własnej winy, nie zna jego sytuacji domowej i nawet nie próbuje mu pomóc. Nauczycielka wychowania fizycznego nie ma nawet cienia empatii dla dojrzewającej, nieatrakcyjnej dziewczyny. Nastolatki zamawiają na obiad tylko sałatę i wymuszają wymioty po jej zjedzeniu. Nikt tego nie zauważa. Nikt nie reaguje. No i przede wszystkim - do szkoły wchodzą po zęby uzbrojeni uczniowie. Przedtem zaś zamawiają i próbują w domu broń, oglądają z zachwytem filmy o nazistach i z całkowitym spokojem rozpisują plan masakry własnej szkoły. Tuż przed strzelaniną biorą wspólny prysznic, całują się (bo nigdy jeszcze tego nie robili²) i życzą sobie powiedzenia słowami: „urządzimy sobie dzień sportu. Najważniejsza jest dobra zabawa”. Codzienność okazuje się nie tak zwyczajna, ale bardzo skomplikowana. Jennifer A. Rich sposób prowadzenia filmowej narracji w Słoniu nazywa dialektyką typową dla horrorów (Rich, 2012: 1314). Reżyserzy tego typu filmów atmosferę grozy budują poprzez naznaczanie strachem sytuacji kojarzących się pozytywnie. Dlatego przerażają filmy, których akcja dzieje się w domu, a bohaterami są zabawki czy małe dzieci. Przez to, że kojarzą nam się z poczuciem bezpieczeństwa i niewinnością, groza nasila się. Podobnie jest w Słoniu. Przez kilka minut widzimy piękne niebo, ale niepo-

\footnotetext{
${ }^{2}$ Gus Van Sant momentami dość stereotypowo postrzega problemy młodzieży i związki przyczynowo skutkowe między nimi. Ukazanie (niemal jednocześnie) wątków fascynacji grami komputerowymi, nazizmem, bronią i wątku homoseksualnego może budzić sprzeciw, a film o trudnym dorastaniu zaczyna jawić się jako zaangażowany ideologicznie (por. Porton, 2003: 52).
} 
koimy się, bo przez to nie jesteśmy świadkami jakiejś szkolnej sceny (słyszymy tylko odgłosy) (Rich, 2012: 1320). Widzimy problemy bohaterów, narastające emocje, a jedyne, co oferuje nam reżyser, to kilka minut podążania za plecami jednego z uczniów. Van Sant operuje też napięciem między budowaniem sympatii i antypatii do bohaterów. W jednej chwili jest nam żal dziewczyny, którą atakują w rozmowie szkolne przyjaciółki, by za chwilę zobaczyć ją samą, jak drwi $\mathrm{z}$ innej uczennicy (potem zaś wymiotuje w szkolnej toalecie, co znów może wzbudzić negatywne emocje, a może wręcz przeciwnie, ogromne współczucie) (Rich, 2012: 1318). Balansowanie między sympatią/antypatią, współczuciem/oburzeniem pozwala odczuć napięcie, które musi być udziałem uczniów tej dziwnej w swojej normalności społeczności szkolnej.

Po projekcji proszę studentów, żeby opowiedzieli, jak to jest być uczniem i nastolatkiem z perspektywy każdego z bohaterów. Dochodzimy zwykle do wniosków, że po broń mógł sięgnąć każdy z tych uczniów, bo każdy borykał się $\mathrm{z}$ problemami. Film to zbiorowy portret młodzieży (K. Jones, 2003: 28). Alkoholizm rodziców, wykluczenie rówieśnicze, zaburzenia odżywania - to ich codzienność. Masakra, która miała miejsce w szkole, jest jakby sumą napięcia, samotności, wykluczenia, złości bohaterów. Zresztą stąd tytuł filmu, Słoń. Inspiracją reżysera była buddyjska opowieść, w której kilku ślepców dotyka różnych części słonia - ucha, nogi, ogona, kłów itp. Każdy ze ślepców jest przekonany, że znajomość tej jednej części pozwala mu na zrozumienie prawdziwej natury zwierzęcia. Jeden zatem twierdzi, że słoń jest jak wachlarz, inny - że jak drzewo, lina, wąż lub też dzida. Żaden jednak nie jest w stanie ogarnąć całości. Dopiero suma ich wrażeń dałaby odpowiedź na pytanie, czym jest słoń (Rich, 2012: 1314). Tak samo jest $\mathrm{w}$ filmie. Napięcie budują wszystkie doświadczenia uczniów, a nie jedynie doświadczenia Erica i Alexa. Jak podsumował film jeden z moich studentów: Ta szkoła symbolicznie rozstrzelała się sama... Problemy młodych ludzi sumują się, kiedy widzimy je wszystkie, i to pokazane $z$ takim spokojem, jest to kumulacja nie do zniesienia dla widza. Tym bardziej nie do zniesienia dla bohaterów. W końcu siła ta powoduje eksplozję.

Podobnie można odczytywać dwa pozostałe filmy, które omawiam w tym tekście. Według Erici J. Dymond, Stephen King budował postać Carrie właśnie wokół słowa „eksplozja”, które znaczy tyle, co „spowodowanie rozpadu czegoś na kawałki poprzez użycie sił będących wewnątrz" (Dymond, 2013: 97). Eksplozja jest zawsze następstwem reakcji wewnętrznych. Film spina jak klamra motyw menstruacji. W pierwszej i ostatniej scenie bohaterki doznają intensywnych krwawień menstruacyjnych, nieprzypadkowo też podczas balu Carrie zostaje oblana krwią (De Palma dobrze wykorzystuje motyw koloru czerwonego w obrazie filmowym. Czerwień jest kolorem Carrie. Symbolizuje zarówno jest dojrzewanie płciowe i rozwijającą się seksualność jak i fakt bycia ofiarą matki i rówie- 
śników; Ehlers, 1981: 36). Procesy destrukcji, których źródłem jest Carrie, podobne są właśnie do menstruacji - są wynikiem tego, co dzieje się wewnątrz dziewczyny. Jak opisuje to Erica J. Dymond, w Carrie kumulują się jej traumatyczne doznania i kiedy dochodzi do momentów kulminacyjnych dziewczyna niszczy otoczenie z pełnym spokojem, cały proces toczy się bowiem w jej wnętrzu. W warstwie fabularnej King pokazuje jak dziewczyna „wciela”, czyni posłuszną częścią siebie otoczenie. Służy temu na przykład pokazanie próby spowodowania powodzi podczas balu. Według opisu autora dziewczyna widziała w głowie obraz rur wewnątrz ścian, czuła ich metaliczny posmak w ustach, przepełniał ją chłód wody (King, 1974: 147). Ona stała się na chwilę systemem przeciwpożarowym i własnymi myślami mogła go uruchomić. Ale to tylko metafora. Zarówno książka jak i film pokazuje dziewczynę, która całe życie gromadzi ładunek emocjonalny, który w końcu eksploduje. Zupełnie jak w Słoniu. Twarze Carrie, Erica i Alexa w momentach katastrof są podobne - nie widać na nich emocji. Emocje zostały uzewnętrznione poprzez strzały, wybuchy, powódź, ogień.

David Jenkins analizuje Carrie jako przykład filmu, w którego fabułę wbudowany jest mechanizm koszmaru sennego. W tym odczytaniu Carrie jest narracją o śnie nastolatki, która doświadcza ogromnej przyjemności bycia wybraną na królową balu, by za chwilę doznać upokorzenia na oczach całej szkoły (Jenkins, 2012: 104). W rozmowach ze studentami częściej pojawia się wątek odczytania jako sen tego, co u Jankinsa jest przebudzeniem: masakry, którą powoduje Carrie. W sporej część książka Kinga to powieść epistolarna - autor zamieścił w niej listy, wycinki z gazet, fragmenty książek poświęcone telekinezie. Jakby głównym problemem Carrie były jej zdolności telekinetyczne, nad którymi straciła kontrolę. Ale to nie jest książka o telekinezie, tylko o dziewczynie osamotnionej przez zajętą sobą i brutalną matkę, o odrzuceniu rówieśniczym, o publicznym upokorzeniu, o dorastaniu na przekór rodzinie. Może widzimy fantazję dziewczyny, która w swej słabości marzy o supersile, o telekinezie umożliwiającej zabicie wszystkich prześladowców? Jej sny? King pisze, że gdy matka znęcała się nad Carrie z nieba padał deszcz meteorów, ściągnięty przez siły dziewczyny. A może zamknięte w ciemności dziecko wyprodukowało ten deszcz we własnej głowie? Bo co innego mogło zrobić? Jak powiedział o filmie Nad krawędziq lider grungowego zespołu Nirvana, Kurt Cobain: „ten film w dużej mierze zdefiniował moją osobowość (...). Totalna anarchia” ${ }^{3}$ Z Z biograficznego obrazu Kurt Cobain: Montage of Heck dowiadujemy się, że twórcy Nad krawędzią pokazali największe marzenie młodego Cobaina. Zamknąć wszystkich dorosłych w jednym miejscu jako zakładników ${ }^{4}$. Może to właśnie tylko fantazje i marzenia o zniszczeniu

\footnotetext{
${ }^{3}$ http://www.imdb.com/title/tt0079688/trivia, dostęp: 18.08.2015.
}

${ }^{4}$ B. Morgen (reż.), Kurt Cobain: Montage of Heck, USA 2015. 
okrutnego, nieprzychylnego młodzieży świata widzimy w omawianych filmach? W Nad krawędzia miesza się dość stereotypowo pokazany świat młodzieży z zamożnych rodzin, w których są pieniądze, ale nie ma czasu i zrozumienia, i dzieciaków z robotniczych blokowisk zostawionych przez zapracowanych rodziców samym sobie. New Grenada to wspólny świat tych dzieci, które żyjąc w miejscu $z$ dala od innych społeczności, zdane są tylko na siebie i muszą same zorganizować swój świat. Pojawiają się w nim używki i broń, dzieciaki z nudów eksperymentują i przekraczają stawiane przez rodziców granice. Dorośli chcą im zabrać ostatni kawałek świata, który uważają za naprawdę swój, i zbudować $\mathrm{w}$ tym miejscu biurowce. Rzeczywiste akty wandalizmu mogą więc być rozpatrywane symbolicznie, a nawet jako młodzieńcza fantazja: symboliczne jest zamknięcia $w$ jednej sali dorosłych, a więc jakby odebranie im głosu i oddanie dzieciom ich praw. Symboliczny (może tym razem to fantazja dorosłych?) jest też autobus, który zabiera złą, zdemoralizowaną młodzież daleko od New Grenady - odnosimy wrażenie, że mimo wszystko to dorośli przegrali stwierdzając, że problemu lepiej się pozbyć, niż się z nim zmierzyć.

$\mathrm{Z}$ jednej strony omawiane filmy to symboliczne opowieści o trudach dorastania i fantazjach na temat spektakularnych sposobów zmierzenia się z nimi. $\mathrm{Z}$ drugiej jednak odbija się $\mathrm{w}$ nich realny świat. To nie tylko zły sen. To koszmarna rzeczywistość. Inspiracją filmu Nad krawędzią były prawdziwe wydarzenia, które miały miejsce w Foster City w Kalifornii na początku lat 70. Bruce Koon i James A. Finefrock zamieścili w „San Francisco Examiner” artykuł pod tytułem: Mousepacks: Kids on a Crime Spree. Tekst jest zapisem aktów młodzieńczego wandalizmu. Czytamy w nim:

To zdaje się być jak scenariusz filmu Mechaniczna Pomarańcza, koszmar senny, futurystyczne fantasy. Ale te wydarzenia są prawdziwe. Miały miejsce w Forester City, mieście, dla którego gang nastolatków „Mousepacks” stanowi jeden z największych problemów kryminalnych $^{5}$. (Koon, Finefrock, 1973: 1, 9)

Scenarzysta Tim Hunter, przeczytał artykuł i stwierdził, że jest to temat na scenariusz filmowy. Autorzy filmu, wybierając na bohaterów dzieciaki przypominające $\mathrm{w}$ realnym życiu granych przez siebie bohaterów, poprzez pewną niedbałość w kręceniu scen osiągnęli, jak pisze Mike Sacks, autentyczność tak intensywną, że wydaje się, jakby chwilami film był dokumentem (Sacks, 2009). Casting do Słonia był podobny. Bohaterów rekrutowano spośród lokalnej młodzieży. „Aktorzy” mieli do dyspozycji luźny scenariusz, większość dialogów wy-

\footnotetext{
${ }^{5}$ Tłumaczenie własne. Dziękuję redakcji „San Francisco Examiner”, która na moją prośbę udostępniła mi numer z 11 listopada 1973 roku.
} 
myślali sami ${ }^{6}$. Eva Zamojska, odczytując obraz szkoły ukazany w filmie Klasa, podobne zabiegi nazywa "fikcją rzeczywistości”, hybrydą. Tego typu obrazy łączą w sobie „walory artystyczne (...) ze świeżością, autentycznością i brakiem schematyczności, które są charakterystyczne dla dokumentu. To maksymalne zbliżenie filmu do rzeczywistości nie służy zamazaniu różnic (...), lecz powiedzeniu czegoś istotnego o samej rzeczywistości, w sposób zarazem uniwersalny i bardzo osobisty" (Zamojska, 2011: 87). Paradokumantalny wymiar Nad krawędzią poza nawiązaniem do prawdziwych wydarzeń i obsadzeniem $w$ roli bohaterów amatorów wzmacnia też fakt, że wymyślone miasteczko, New Grenada, powstało w Kolorado, godzinę drogi od miejsca, gdzie za 20 lat rozegra się masakra w Columbine High School. Jest to smutny, dziwaczny zbieg okoliczności (Sacks, 2009), który pokazuje też aktualność i ponadczasowość poruszonych w filmie problemów. Gus Van Sant, reżyser Słonia, rekonstruuje w swoim filmie właśnie tę zbrodnię̧: w 1999 roku, w Columbine High School dwóch uczniów zabiło kilkunastu kolegów. Motywem masakry, jak mówili chłopcy planując ją, było zrobienie show, które przejdzie do historii ${ }^{8}$. Także filmowi Alex i Eric są wyzuci z emocji, zdaje się, że cyniczni. Można zakładać, że łączy ich relacja przyjacielska, ale gdy z zimną krwią planują zbrodnię relacja ta wydaje się być powierzchowna, zogniskowana tylko wokół chęci rozprawienia się z własną szkołą. Oglądając film, mam wrażenie, że to nie ludzie, ale jedna z masek nastolatków odpowiadająca im akurat $\mathrm{w}$ danym czasie.

Zbyszko Melosik w odniesieniu do współczesnego trybalizmu pisze o mnogości powierzchownych relacji, w które wchodzą nie tyle ludzie, ile ich wizerunki (Melosik, 2013: 69), przez co rzeczywistość upodabnia się do portalu społecznościowego. Nagrania chłopców z Columbine High School przed masakrą i w jej trakcie to czarny spektakl wizerunków i zapowiedź: będziemy sławni. Gus Van Sant nie realizuje jednak swoim filmem makabrycznych marzeń chłopców o popularności (choć to można mu zarzucić). On nie przyczynia sie do promocji wizerunków wymyślonych, ale odkrywa prawdę, pokazuje, że nie chodziło tylko o show, ukazuje skomplikowane losy nastolatków, uczniów każdej szkoły. Pokazuje ich bezradność i samotność. Dekonstruuje maskę, za którą ukryli się młodociani przestępcy - odkrywa ją w postaciach pozostałych uczniów, pozwalając, by dwóch głównych bohaterów prawie ani na chwilę nie wyszło poza wymyślony przez chłopaków z Columbine High School wizerunek (wyjątkiem jest chyba scena, w której Alex i Eric ostrzegają jednego z kolegów, Johna, żeby uciekał ze

\footnotetext{
${ }^{6} \mathrm{http}: / /$ stopklatka.pl/wiadomosci/-/6964299, nagrodzony-zlota-palma-w-cannes-slon-juz-w-kinach, dostęp: 18.08.2015.

${ }^{7}$ Nic dziwnego, że film Słoń jest przywoływany w kontekście Nad krawędziq i odwrotnie. Por. Stephens, 2005: 78 .

${ }^{8} \mathrm{http} / / /$ www.acolumbinesite.com/quotes1.html, dostęp: 16.08.2015.
} 
szkoły, bo będzie się tam działo coś strasznego). Czy jednak widz osądza ich negatywnie? I oni, nawet $\mathrm{w}$ końcowej scenie, gdy jeden bez mrugnięcia okiem morduje drugiego, wzbudzają empatię i współczucie. Nie ma jednak gotowych odpowiedzi na wiele pytań i ocen zdarzeń oraz zachowań bohaterów. „Formuła paradokumentu wcale nie ułatwia (...) odczytania jego znaczeń. Przeciwnie - tak jak prawdziwe życie dopuszcza wielość interpretacji, tak doskonała «fikcja rzeczywistości» staje się przeszkodą w wyciąganiu jednoznacznych wniosków. Twórcy zdają się nam mówić: tak to się działo (dzieje w dzisiejszej szkole) (...), lecz nie mamy pewności, co o tym należy sądzić" (Zamojska, 2011: 87). Emocjonalny ładunek wybuchowy, który gromadzą bohaterowie Słonia, Nad krawędzia czy Carrie nie pozwala na jednoznaczne potępienie ich czynów. Widz może w jakiś sposób z nimi sympatyzować, współczuć im czy się z nimi utożsamiać bardziej niż krytycznie ich osądzać. Jak napisano w jednej z recenzji Słonia, „film niezależnie od niepokoju, jaki wzbudza, wywołuję wielką sympatię - sympatię bez oceny. Nieważne, z którym z bohaterów się identyfikujesz - problemy nastolatków są uniwersalne. Każdy z nich przeżywa podobną burzę hormonów i poszukuje tożsamości"'.

Gdy rozmawiam ze studentami o przywołanych w tym tekście filmach, idąc tropem Van Santa, dekonstuujemy pewną maskę, składamy w całość słonia z przypowieści. Widzimy jednych bohaterów w drugich - ktoś dostrzega w zakompleksionej Michelle Carrie, ktoś łączy obrazy rodzin pokazane w Nad krawędziq ze strzępkami takich obrazów w Słoniu. Nieprzypadkowo King wybrał na miejsce i czas ostatecznej masakry mury szkoły i czas balu. Przecież jest to rytuał tak typowy dla amerykańskiej szkoły, że chyba nic lepiej jej nie symbolizuje (Ehlers, 1981: 35). King zaznacza mocno: tak, to opowieść o każdej szkole. O problemach, które są tak ogromne, że w końcu symbolicznie, albo realnie muszą wybuchnąć. Jak napisał o Słoniu jeden z recenzentów: to elegia na piękno i witalność młodych ludzi (Cunneen, 2003, s. 20).

Wnioski, do których dochodzimy podczas zajęć wokół filmów, wracają do nas przy okazji wielu omawianych tematów. Rozmawiamy o szkole jako tyglu, w którym mieszają się przeżycia i doświadczenia młodych ludzi pytając, co może w różnych sytuacjach zrobić nauczyciel. Ta dyskusja, co podkreślają studenci, jest trudna i ważna. I zostaje $w$ nas jak obrazy $z$ tych trzech filmów. Trudno je zapomnieć.

Fakt, że filmy oglądane podczas zajęć i dyskusje, które były wokół nich prowadzone, zostają w pamięci studentów, może być punktem wyjścia refleksji nad sensem pracy z obrazami filmowymi podczas zajęć. Zdarza mi się, że spotykam studentów kilka lat po zakończeniu kursu pedagogiki. Nie pamiętają wszystkich

${ }^{9} \mathrm{http}: / /$ film.onet.pl/wiadomosci/glosy-prasy/x5rj4, dostęp: 18.08.2015. 
treści z zajęć, zawsze jednak odtwarzają tematy, którym towarzyszyły obrazy filmowe. Jest to zapewne związane z psychologicznymi mechanizmami pamięci: lepiej zapamiętujemy elementy zakodowane $\mathrm{w}$ dwóch systemach - słownym i obrazowym (dlatego elementem wielu mnemotechnik jest wytwarzanie wyobrażeń obrazowych zapamiętywanych słów) i materiał, z którym pracujemy (np. dyskusje), którym manipulujemy (Jagodzińska, 2008: 247). Dlatego filmy mogą być dopełnieniem podręcznika (np. filmy historyczne), ale nie tylko. Traktuje się je też jako „wyzwalacz” skojarzeń: poprzez filmową metaforę szuka się analogii do procesów społecznych, film może być nawet prowokacją do podejmowania jakiś działań (Russell III, 2012: 158). Filmy są szczególnie użyteczne, jeśli chcemy pracować nie tylko na treściach, ale i na emocjach. Są na przykład skuteczną metodą edukacji moralnej - uwrażliwiają, skłaniają do refleksji, kształtują wyobraźnię (Wonderly, 2009: 9). Są znakomitym głosem w dyskusjach dyskusji na tak zwane trudne tematy, co w swoich badaniach potwierdziły na przykład Audrey Smith Rorrer i Susan Furr (Rorrer, Furr, 2009: 162-168). Podczas kursów dla przyszłych nauczycieli prezentowały one różne obrazy filmowe prowokując do dyskusji wokół zagadnień wielokulturowości w edukacji. Wzrost świadomości i wrażliwości studentów w tym obszarze pozwolił badaczkom nazwać filmy „narzędzia świadomości wielokulturowej" w edukacji przyszłych nauczycieli. Badania nad rolą filmu w przygotowaniu do zawodu nauczyciela prowadzili także Alper Kaçkaya, Ihsan Ünlü, M. Said Akar i Meryem Özturan Sagirli. Dowiedli oni, że włączenie do zajęć filmów, których bohaterami są zmagający się z codziennymi trudami nauczyciele, znacząco pozytywnie wpływa na ocenianie własnej skuteczności zawodowej i samego zawodu nauczyciela przez studentów przygotowujących się do tego zawodu i osoby, które niedawno rozpoczęły pracę (Kaçkaya, Ünlü, Akar, Özturan Sagirli, 2011: 1778-1783). Autorzy swoje rozważania lokują w odniesieniu do kategorii nauczyciela - refleksyjnego praktyka, konstatując, że filmy w różnego rodzaju kursach przygotowujących do zawodu pomagają rozbudzać tę postawę (Kaçkaya, Ünlü, Akar, Özturan Sagirli, 2011: 1779). Swego czasu Maria Dudzikowa w jednym z esejów przywołała monodram Jean-Pierre’a Dopagne’a pt. Belfer. Tytułowy nauczyciel pewnego dnia nie wytrzymuje, wyciąga z teczki karabin maszynowy i jak sam opowiada: „Wypakowałem cały magazynek. Na zimno. Położyłem trupem swoją klasę maturalną" (Dudzikowa, 2007: 32). Przywołuję ten utwór, by za Marią Dudzikową powtórzyć, że szkoła bywa „ziemią nieludzką" nie tylko dla uczniów (Dudzikowa, 2007: 29). Nauczyciele też gromadzą swoje doświadczenia, swoją niemoc, upokorzenia i być może także, jak uczniowie - bohaterowie omawianych przez mnie filmów fantazjują o tym, żeby dać temu wszystkiemu upust. We wszystkich przywoływanych w tym tekście obrazach są to fantazje o brutalnych masakrach, rzadko na szczęście dochodzi do nich w rzeczywistości. Natomiast eksplozja przemocy, 
agresji fizycznej (także skierowanej na siebie samego), słownej, wyśmiewania, milczenia i różne inne destrukcyjne formy radzenia sobie z problemami to rzeczywistość każdej szkoły. Filmy fabularne poruszające te problemy mogą być elementem zajęć, podczas których o tym wszystkim rozmawiamy ze studentami przygotowującymi się do pracy w szkole.

Ciekawym pomysłem na włączenie filmu do kursów pedagogicznych może być także uczynienie studentów nie tylko ich odbiorcami, ale też twórcami. Dzięki temu aktywnie pracuje się ze zdobywaną wiedzą, przekształca ją z pełnym zaangażowaniem. Studenckie filmy korespondujące $\mathrm{z}$ tematyką kursu mogą być na przykład prezentowane jako jego podsumowanie (w miejsce często stosowanych prezentacji) i elementem oceny końcowej (Anderson, 2013: 386). Ponadto jeśli studenci sami są uczestnikami zajęć, podczas których stosuje się metody nauczania inne niż tylko podające, być może jako nauczyciele sami będą po nie chętniej sięgali. Nauczyciele reprodukują w swojej pracy prywatne teorie roli zawodowej, wyrosłe na własnych doświadczeniach i, jak pokazują badania, $\mathrm{w}$ dużej mierze to one mają wpływ na przykład na podejmowane w klasie decyzje (Chant, Heafner, Bennett, 2004: 26). Zwykle reprodukowany jest transmisyjny model nauczania. $\mathrm{W}$ tym modelu rolę nauczyciela utożsamia się $\mathrm{z}$ dawaniem gotowych rozwiązań problemów, przekazywaniem wiedzy w sposób jasny i uporządkowany. Tradycyjne podejście do nauczania, obecne we własnych doświadczeniach szkolnych, jest tak głęboko zakorzenione, że dominuje wiedzę zdobywaną $w$ ramach przygotowania do wykonywania zawodu nauczyciela (Richardson, 1997: 3) i dlatego jest reprodukowane w praktyce pedagogicznej. Pokazuje to na przykład raport Teaching and Learning International Survey (TALIS), który powstał $\mathrm{w}$ ramach badań porównawczych prowadzonych w 23 krajach (na próbie 70 tysięcy nauczycieli). Wśród objętych badaniem problemów były rozwój zawodowy, nauczycielskie przekonania, postawy i praktyki. Okazało się, że nauczyciele z większości badanych krajów częściej deklarują używanie tradycyjnych metod przekazywania wiedzy niż metod aktywizujących ${ }^{10}$.

Mimo rozmaitych możliwości zastosowania filmu, także fabularnego, w edukacji, z własnych doświadczeń wiem, że filmy traktowane są przez niektórych nauczycieli i wykładowców jako coś, co niepotrzebnie zajmuje czas. Ogląda się je na przykład na ostatnich zajęciach przed świętami, kiedy jest niska frekwencja. Wpływa to negatywnie na postrzeganie przez studentów wartości przesłania pedagogicznego tych obrazów. Tymczasem można traktować je zupełnie inaczej: nie jako zastępstwo nauczyciela czy wykładowcy, ale jako skuteczne narzędzie

\footnotetext{
${ }^{10}$ Creating Effective Teaching and Learning Environments: First Results from TALIS, http://www. oecd.org/edu/school/creatingeffectiveteachingandlearningenvironmentsfirstresultsfromtalis.htm, dostęp: 18.08.2015; patrz. szerzej: Klichowski, Bonanno' Jaskulska, Smaniotto Costa, de Lange, Klauser, 2015.
} 
angażujące do autentycznej pracy intelektualnej z ważnymi treściami i problemami (Stoddard, Marcus, 2010: 89).

Wrócę na zakończenie do przywoływanego już eseju Marii Dudzikowej. Analizując przyczyny masakry, którą spowodował w swojej klasie Belfer, pisze ona o zderzeniu dwóch światów

z jednej strony uczniowie, upodobnieni wyglądem do ikon kultury popularnej i uczący się „od idoli” codziennych zachowań, zajęci swoimi potocznymi sprawami wyznaczonymi rytmem i problemami ich życia w rozmaitych blokowiskach, z drugiej zaś strony „belfer od literatury”, zapatrzony we wzór osobowy swego dawnego nauczyciela łaciny i greki, pragnący tak jak kiedyś on „władać umysłami” uczniów i być „mentorem spragnionej wiedzy młodzieży”, ale już teraz bez złudzeń w sukces własnej misji. (Dudzikowa, 2007: 31)

Przesłanie o zderzeniu dwóch światów, dzieci/młodzieży/uczniów i dorosłych/nauczycieli/rodziców, na przecięciu których może dojść tylko do eksplozji, to jeden $\mathrm{z}$ wątków wszystkich przywoływanych przeze mnie obrazów. Z jednej strony filmy te mogą uwrażliwiać na te właśnie problemy, z drugiej, zachęcać studentów, by sami też kiedyś sięgali w swojej pracy po materiały aktywizujące (film za kilka lat z pewnością będzie przeżytkiem, ale metod nauczania wspieranych przez nowe technologie stale przybywa; por. Klichowski, Bonanno, Jaskulska, Smaniotto Costa, de Lange, Klauser, 2015), by wychodzili poza schematy, nie bali się poruszać z uczniami trudnych (czasem kontrowersyjnych) tematów w przystępny sposób. By w miejscu, gdzie łączy się świat ucznia i nauczyciela, działo się coś ważnego ale i ciekawego.

\section{Literatura}

Anderson J. (2013). Active Learning through Student Film: A Case Study of Cultural Geography. "Journal of Geography in Higher Education" Vol. 37, No. 3.

Chant R.H., Heafner T.L., Bennett K.R. (2004). Connecting personal theorizing and action research in preservice teacher development. "Teacher Education Quarterly" 31(3).

Creating Effective Teaching and Learning Environments: First Results from TALIS, http://www.oecd. org/edu/school/creatingeffectiveteachingandlearningenvironmentsfirstresultsfromtalis.htm [dostęp: 18.08.2015].

Cunneen J. (2003). "Elephant" is elegiac. "National Catholic Reporter" 21 November.

Dudzikowa M. (2007). Pomyśl siebie... Minieseje dla wychowawcy klasy. Gdańsk.

Dymond E.J. (2013). An examination of the use of gendered languagein Stephen King's CARRIE. “The Explicator” Vol. 71, No. 2.

Ehlers L.A. (1981). „Carrie”. Book and film, “Literature/Film Quarterly” No 1.

http://film.onet.pl/ wiadomosci/glosy-prasy/x5rj4, dostęp: 18.08.2015. 
http://stopklatka.pl/wiadomosci/-/6964299,nagrodzony-zlota-palma-w-cannes-slon-juz-w-kinach, dostęp: 18.08.2015.

http://www.imdb.com/title/tt0079688/trivia, dostęp: 18.08.2015.

Jagodzińska M. (2008). Psychologia pamięci. Badania, teorie, zastosowania. Gliwice.

Jenkins D. (2012). The Nightmare and the narrative. "Dreaming” Vol. 22, No. 2.

Jones K. (2003). Corridors of powerlessness: Elephant. "FilmComment" No. 9-10.

Kaçkaya A., Ünlü I., Akar M. S., Özturan Sagirli M. (2011). The effect of school and teacher themed movies on pre-service teachers' professional attitudes and perceived self-efficacy. "Educational Sciences: Theory \& Practice" 11(4).

King S. (1974). Carrie. New York.

Klichowski M., Bonanno P., Jaskulska S., Smaniotto Costa C., de Lange M., Klauser F.R. (2015). CyberParks as a new context for smart education: theoretical background, assumptions and preservice teachers' rating. "American Journal of Educational Research" No. 3(12).

Koon B., Finefrock J.A. (1973). Mousepacks: Kids on a Crime Spree. "San Francisco Examiner" 11 Nov.

Melosik Z. (2013). Kultura popularna i tożsamość młodzieży. W niewoli władzy i wolności. Kraków. Porton R. (2003). Festival de Cannes 2003. "Cineaste” Fall.

Rich J.A. (2012). Shock corridors: the new rhetoric of horror in Gus Van Sant's Elephant, "The Journal of Popular Culture" Vol. 45, No. 6,

Richardson V. (1997). Constructivist teaching and teaching education: Theory and practice. [In:] V. Richardson (ed.). Constructivist Teacher Education: Building a World of New Understandings. Bristol.

Rorrer A.S., Furr S. (2009). Using film as a multicultural awareness tool in teacher education. "Multicultural Perspectives" 11(3).

Russell III W.B. (2012). The art of teaching social studies with film. "The Clearing House" 85.

Sacks M. (2009). Over the Edge. "Vice”, 1 September, http://www.vice.com/read/over-the-edge134-v16n9, dostęp: 18.08.2015.

Stephens Ch. (2005). Recommended: Over the Edge. "FilmComment".

Stoddard J.D., Marcus A.S. (2010). More than ,showing what happened”: exploring the potential of teaching history with film. "The High School Journal" Jan/Feb..

Wonderly M. (2009). Children's film as an instrument of moral education. "Journal of Moral Education" Vol. 38, No 1.

Zamojska E. (2011). Szkoła w filmie. Czy tylko fikcja? Analiza obrazu rzeczywistości szkolnej $w$ filmie „Klasa” („Entre les murs”). [W:] W. Jakubowski, S. Jaskulska (red.). Kultura mediów, ciało i tożsamość - konteksty socjalizacyjne i edukacyjne. Kraków.

\section{Filmografia}

De Palma B. (reż.), Carrie, USA 1976.

Kaplan J. (reż.), Nad krawędzią, USA 1979.

Morgen B. (reż.), Kurt Cobain: Montage of Heck, USA 2015.

Van Sant G. (reż.), Stoń, USA 2003. 